\title{
Idioms in the works of G. Chaucer and W. Shakespeare as signatures of social environment
}

\author{
R. Y. Kritsberg
}

Independent Scholar, Translator in Jewish Community, Dortmund, Germany

Corresponding author. E-mail: roman.kritsberh@fulbrightmail.org

Paper received 05.04.20; Accepted for publication 26.04.20.

\section{https://doi.org/10.31174/SEND-Ph2020-226VIII68-05}

\begin{abstract}
Idioms in G. Chaucer's and W. Shakespeare's works reflect the social environment of their time. People's professional activities and pastimes, such as military, law, hawking, hunting, are among the most productive sources of set expressions. In terms of refentiality, there are two classes of the items - the former includes those of non-equivalent vocabulary, with no corresponding notions and their expressions in Modern English, and the latter compises those with different present-day counterparts for the same notions.

Keywords: cultural background, diversions, idioms, lexical items, proverb.
\end{abstract}

Introduction. The lexis of any language reflects its social environment in a straight and direct way, contrary to elements of its other levels - phonology, morphology, syntax. Due to nominative function, lexical items constantly replenish the language stock to meet the requirements of naming new ideas, objects, which keep appearing in a society. Idioms and set expressions constitute a very telling part of the lexis, since they crystallize cultural markers of a given time and space. Their study helps shed light on societal practices and attitudes. From this angle, the study of idioms in the works of G. Chaucer and W. Shakespeare in the Late Middle-Early Modern English is especially topical issue.

Survey of publications. The sources on the language of G. Chaucer and W. Shakespeare are abundant. One can mention such ground-breaking works, as F. Heer on culture in medieval world [5], T. Machnam on English in the Middle Ages [6], J. Forgeng and W. McLean on the Chaucer's England [4], A. Malcolm on the Chaucer's language [7], N. Drake [3] and E. Shewmaker [9] on W. Shakespeare's language and time. Still, the problem under consideration lacks the adequate study.

Objective, material, methodology. The paper's objective is to reveal the signatures of professional activities and pastimes of the above-stated period in the works of G. Chaucer [2] and W. Shakespeare [8], which serve as material for present study. Its methodology includes methods of comparative, descriptive and discourse analysis.

Results and discussion. First, it is necessary to mention that cultural background looms behind old sayings. Thus, the old proverb out of God's blessing into the warm sun apart from general meaning 'in a worse situation' was used in a legal sense 'cut off with a shilling, deprived of heritage', as: 'King. 'How is it that the clouds still hang on you?' Ham. 'Not so, my lord; I am too much i' the sun." [8, Hamlet. I. ii. 66-67]. Or, in the first act Hamlet speaks of the king's boisterous reveling: "The king doth wake tonight and takes his rouse, Keeps wassail and the swaggering up-spring reels." [ibid, I. iv. 8-9]. Here - upspring (German Hüpfauf) used to be 'the last and consequently wildest dance at the old German merry-making'.

Let's consider the case, when old proverbs and idioms reflect old traditions and practices, which are out of use nowadays. One of the most popular diversions in the Middle Ages was hawking. Thus, the character from The Canterbury Tales, states: "With empty hand men may none haukes lure." [2, The Wife of Bath's Prologue. 415] - "Men cannot lure hawks with empty hand." Hawking, as N. Drake points out [3, p. 125], was introduced into Great Britain in the 8 century and until the beginning of the 16 , was the privilege of the nobility, then later "descended to the gentry and wealthy yeomanry" [ibid]. Hawking was a science in itself that included the particulars about the game pursued, land and water hawking, horseback or foot hawking, along with training of hawks. The last consisted in the manning, luring, flying and hooding them [ibid, p. 130]. It is the luring, bringing hawks to the lure (an object stuffed like that kind of bird the hawk was designed to pursue) and making them jump to the fist, was the most laborious. Eyas was a young hawk taken from the nest for the purpose of training, young untrained hawk and eyas-musket (obsolete 'a kind of sparrow-hawk') meant also 'lively child'. W. Shakespeare uses the image quite often: "Mrs. Ford. How now, my eyas-musket! What news with you?" [8, The Merry Wives of Winsdor. III. iii 21-22]. "...but there is, sir, am aery of children, little eyases, they cry out on the top of question." [ibid, Hamlet. II. ii. 362-364].

There are other examples of that kind, when Hamlet answers Horatio and Marcellus by words "come, bird, come" [ibid, I. V. 115], the way falconers used to call the birds. Or Claudius conspiring with Laertes to do away with Hamlet says: "If he be now return'd, As checking at his voyage, and that he means No more to undertake it." [ibid, IV. vii. 6163]. Here, the reference is made to the expression to check at the fist 'to refuse to come, to recoil at the fist, to be shy (of a bird)'. The saying between hawk and buzzard reflects the difference between a good sporting bird and its lazy kind, useless for falconry and is current nowdays.

Hunting was another great diversion in the Middle Ages, which took over hawking with the adoption of the gun. This sport varied in style, place, manners, and other subtleties people used in slaughtering animals. There many references in G. Chaucer's works to this practice, as as prikyng ('tracking of a hare by its footprints') and huntyng for the hare [2, General Prologue, 191]. Other examples: "For in this world nys dogge for the bowe That kan an hurt deer from an hool yknowe Bet than this somnour knew a sly lecchour, Or an avowtier, or a paramour." [ibid, The Friar's Tale. 13691372]. - "This summoner knew a sly lecher, or an adulterer, or a concubine better than the best dog, which hunts with an archer and knows a wounded deer from a sound one." "And eek to Januarie he gooth as lowe As evere did a dogge for the bowe." [ibid, The Merchant's Tale. 2013-2014]. - "And then to January he goes so obediently, As a trained dog to accompany an archer."

Many allusions, metaphors, and references related to the hunting are found in W. Shakespeare's works. Thus, a hunter used to run a risk on delivering the death-stroke to the wounded enraged animal at bay, especially those equipped 
with horns, as stags. The archaic expression horn-mad (earlier wood-mad) 'stark mad, furious' exemplifies this situation, along with mad as a buck, E.g.: "...if I have horns to make me mad, let the proverb go with me; I'll be horn-mad." [8, The Merry Wives of Winsdor. III. v. 157-158]. "It would make a man mad as a buck to be so bought and sold." [ibid, The Comedy of Errors. III. i. 71-72].

Canines are indispensable part of the diversion. Thus, the old saying when night dog run all sorts of deer are chased [ibid, The Merry Wives of Windsdor. V. v. 263-264] can be compared to the modern all cats are gray in the dark. There is another passage where two hunting terms are combined: to draw (hunt) dry-foot 'to track the game by the mere scent of the foot' and to run counter 'to follow the scent or trail of the game in the reverse direction', with both producing the figurative effect of unscrupulous person: "One whose heart is button'd up with steel; A fiend, a fairy, pitiless and rough; A wolf, nay, worse, a fellow all in buff;... A hound that runs counter and yet draws dry-foot well One that, before the judgment, carries poor souls to hell." [ibid, The Comedy of Errors. IV. ii. 34-40].

The game was driven in the direction, in which the wind was blowing, lest it should smell the trap, as in the following: "To withdraw with you: why do you go about to recover the wind of me, as if you would drive me into a toil [=trap]." [ibid, Hamlet. III. ii. 367-369]. Birds used to be caught with the lime (viscious sticky substance prepared from the bark of the holly), and the act is reflected in a number of figurative expressions, referring to the human gullibility and greenness, as: "Poor bird! thou'dst never fear the net nor lime, The pitfall nor the gin." [ibid, Macbeth. IV. ii. 34-35]. "You must lay lime to tangle her desires By wailful sonnets, whose composed rimes Should be full-fraught with serviceable vows." [ibid, The Two Gentlemen of Verona III. ii. 68-70]. "O limed soul, that struggling to be free Art more engaged!" [ibid, Hamlet III. iii. 68-69].

It's worth mentioning other diversions of that time, which left their traces in the language. The context can't be clear without knowing the practices. Thus, the game of football is evoked when Dromio of Ephesus from The Comedy of Errors [ibid, II. i. 83-85] complains: "That like a football you do spurn me thus? You spurn me hence, and he will spurn me hither: If I last in this service, you must case me in leather. "Tennis was played with the palm of the hand in the open air and mention in Hamlet ([ibid, I. i. 59]: "There was a' gaming; there o'ertook in 's rouse; There falling out at tennis." The game of bowls played in the bowling-alley is referred to when Polonius wants to find out truth about his son Laertes by indirect means, by assays of bias, whose original sense goes back to the oblique line the bowl runs due to its construction: “... and with assays of bias By indirections find directions out." [ibid, Hamlet. II. i. 65-66]. The famous phrase from the Hamlet's monolog [ibid, III. i. 65] there's the $r u b$ referes to the $r u b$ as 'an obstacle or impediment the ball in the game of bowls is hindered in or diverted from its course' [10, p. 1623].

Dicing has been the scourge of all the times. Hamlet refers to "marriage vows as false as dicers' oaths" [8, III. iii. 44-45] meaning 'untrustworthy, as when a dicer swears never to play the game again each time breaking his promise'. The old game of loggats, as referred to in Hamlet, according to OED [10, p. 991], consisted in stake fixed into the ground, 'those who play, throw loggats at it, and he that is nearest the stake, wins": "Did these bones cost no more the breeding but to play at loggats with'em." [8, Hamlet. V. i. 97-99]. Playing cards echoes in such lexical items as swoopstake [ibid, IV. v. 141] refers to 'sweeping all the stakes at once, hitting the jackpot'. Fistfighting seems to have been 'evergreen' in all times, as attested in the same play: “...there was, for a while, no money bid for argument, unless the poet and the player went to cuffs in the question." [ibid, II. ii. 379-381]. Children's games are well presented in literature of that time, as hoodman-blind, the old equivalent for modern for blindman's buff, or 'hide fox, and all after' [ibid, IV. ii. 32]. Fencing is reflected many times in the works under consideration. In Hamlet, Claudius speaks of "scrimers [= fencers] of their nation, He swore, had neither motion, guard, nor eye." [ibid, IV. vii. 100-101], and later of "pass of practice [round in fencing]" [ibid, 138].

Many lexical items of that time are taken from professional spheres and can be understood through the prism of occupation. Thus, the military gave rise to the expression keep fair quarter with 'have good relations with' (from quarter 'assigned position'), as "So he would keep fair quarter with his bed." [ibid, The Comedy of Errors. II. i. 108]. In Hamlet, the hero compares his tactics to those of miner who lays mines to undermine a fortress and faces countermining: "Let it work; For 'tis the sport to have the enginer Hoist with his own petard: and it shall go hard But I will delve one yard below their mines, And blow them at the moon. " [ibid, III. iv. 205-209]. Another example is point-blank used as adjective, noun, and adverb 'of a gun: aimed or fired horizontally, level, straightforward', used both in literal and figurative senses. E.g.: "And what's untimely done: so, haply slander, Whose whisper o'er the world's diameter, As level as the cannon to his blank Transports his poison'd shot." [ibid, IV. i. 40-43]. "Why, this boy will carry a lettertwenty mile, as easy as a cannon will shoot point-blank twelve score." [ibid, The Merry Wives of Windsor. III. ii. 32-4].

The other examples from the military follow. One of the now obsolete expressions is to cry aim 'to encourage the archers by crying out 'aim!' when they were about to shoot', 'to encourage in general' [10, p. 31]. E.g.: “... and to these violent proceedings all my neighbours shall cry aim." [8, The Merry Wives of Winsdor. III. ii. 45-6]. The idiom in the full bent 'wholeheartedly, with maximum energy, determination or devotion' came from the degree of bending of a bow to be loosened, e.g. "But we both obey, And have give up ourselves, in the full bent, To lay our service freely at your feet, To be commanded." [ibid, Hamlet. II. ii. 29-32]. Another Shakespearean phrase to the top of one's bent deals with the same issue: the maximum bending of a bow and hence limit, degree, capacity: "They fool me to the top of my bent." [ibid, III. ii. 408-409]. In the same tragedy, Claudius deplores that he cannot do away with Hamlet because of his mother's love and common public affection for him: “...so that my arrows Too slightly timbered for so loud [=strong] $a$ wind, Would have riverted to my bow again, And not where I had aim'd them." [ibid, IV. vii. 21-24]. The idiom tickle of the sear refers to 'easily made to go off', it is about the gun with the lock that is immediately released after the lightest touch. E.g.: “...the clowns shall make those laugh whose lungs are tickle o' the sere." [ibid, 346-347].

Another sphere, which used to be rather important in medieval times but now has declined is milling. Mills served as important instrument of the nobility's dominion over the peasantry. F. Heer notes that all villains were under obligation to take all their grain "to the lord's to be ground, for 
which payment was naturally exacted" [5, p. 42]. By the end of the $11 \mathrm{c}$. there were five thousand of water-mills in England, the number equal to that of knights in the army of the king. "The mills like the castles and the bonds of obligation, demonstrated the hold of the baronage over the countryside and its people." [ibid]. That is why the miller played a pivotal role in country's economic life: farmers were dependent on his complicated machinery that gave them final produce of their work. And the reputation of the miller, who allegedly used to give people short measure of their grain, left much to be desired. This is clearly seen in G. Chaucer's The Canterbury Tales: "He [miller] was a jagnlere and a goliardeys, And that was moost of synne and harlotries. Wel koude he stelen corn and tollen thries;And yet he hadde a thombe of gold, pardee." [2, Prologue. 560-563]. - "He was a loud talker and a course buffoon, And has a lot of sins and scurrility. He could steal the corn very well And take three times the legal toll on the corn he ground; And yet he had a thumb of gold, indeed. " Here, there is an allusion to the old proverb "An honest miller has a golden thumb" that means that there are no honest millers.

Many expressions related to law are used by W. Shakespeare, e.g. perpetual durance [8, Measure for Measure. III. i. 66] 'life imprisonment'; to bite the law by the nose [ibid. 107] 'to find the loopholes'. Hamlet in his monolog speaks about one of the dark side of the lawyers's profession that was very important in that time - buying land. The big landowners used to purchase land for sheepraising, being notorious thereby depriving peasants of arable land: "Where be his quiddities now, his quillets, his cases, his tenures, and his tricks? ... This fellow might be in's time a great buyer of land, with his statutes, his recognizances, his fines, his double vouchers, his recoveries ... will his vouchers vouch him no more of his purchases, and double ones too, than the length and breadth of a pair of indentures? The very conveyance of his lands will hardly lie in this box..." [ibid, V. i. 104-120].

Here, quiddity 'subtlety in arguing'; quillet 'verbal nicety'; tenure is the possesion of land by the English Law, tenement; statute (from statute merchant, statute staple) is 'a bond or recognizance by which the creditor had the power of holding the debtor's lands in case of default' [10, p. 1891]; recognizance - 'a bond or obligation itself, pledged as security (sum of money) to be forfeited in case of neglecting the obligations'; fines - 'a comrpomise of a fictious suit for the possessions of lands used to facilitate the land conveyance' [ibid, p. 590]; recovery - 'the legal procedure of gaining possession of some property when some estate is transferred from one party to another'; double voucher - 'summoning a person in the court for land recovery when the fine was to be sued first'; a pair of indentures - 'a contract between two parties with two copies written on one piece of paper then cut asunder in a zigzag line to be checked later, if necessary, for the pieces to be tallied and showed that they were parts of the same original contract' [ibid, p. 836]; conveyance 'transerrance of property by law from one part to another'.

Nobility and heraldry have left visible traces in the works of W. Shakespeare and G. Chaucer. Ophelia, for example, speaks "You may wear your rue with difference." [8, IV. v. 182], where difference is 'an alteration or addition on the coar of arms to distinguish a junior member or branch of a family from a chief one' [10, p. 431]; Laertes deplores "no hatchment" (a kind of ensign armorial, a tablet exhibiting the armorial bearings of a deceased person attached to his house) over his father's bones [8, IV.v. 214].

Professionalisms of other spheres are found in the works of the Late Middle and Early Modern English writers, as in Macbeth "...come in, tailor; here you may roast your goose." [ibid, II. iii. 17], here goose 'a tailor's smoothing iron from the resemblance of its handle to the goose neck [10, p. 691]; "What should be spoken Here where our fate is fate, hid in the auger-hole (=a carpenter's tool)." [8, II. iii. 128-129]; "...The source of this our watch and the chief head Of this post-haste and romage in the land." [ibid, I. i. 106-107]. According to OED [10, p. 1398], the origin of this item came from the old directions on letters "Haste, post, haste!', where post stands for 'courier'; Hamlet calls the Ghost of his father "A worthy pioner!" [8, v. 163], comparing his moving beneath the earth to the work of a miner, digger or excavator.

Next goes the inventory aspect of the study. Many of the above-mentioned items do not have analogs in Modern English. They are closely connected to the realia of that time. On the other hand, very often the old set expressions, out of use nowadays, have counterparts in the modern language. In other words, the same ideas or concepts are expressed differently. Thus, G. Chaucer uses the saying "Whose that first to mille cometh, first grynt;" - "He, who comes first to the mill, grinds first ." [2, The Wife of Bath's Prologue. 389], the modern equivalent is first come, first served. Another old saying to cry aim is the full synonym of the modern one go for it!, which has come from the world of sport. Examples like those are abundant. 'Jack-a-'Lent, for instance, is 'a figure of a man to be thrown by stones', a kind of popular diversion along with its derivative sense 'a scapegoat' corresponds to modern British English Aunt Sally and American English fall-guy, e.g.: "Mrs. Page. You little Jack-a-Lent, have you been true to us? Rob. Ay, I'll be sworn." [8, The Merry Wives of Winsdor. III. iii. 27-29].

The old expression to make a shaft or a bolt of it means 'to run the risk, to accept the issue whatever it may be' [10, p. 155], where bolt was a short and thick arrow discharged from a cross-bow, while shaft was a kind of longer arrow for a long bow (ab. 36 inches). It is the equivalent to the current expressions make or break, etc. E.g.: "Slen. 'I'll make a shaft or a bolt on't, 'Slid, 'tis but venturing." [8, III. iv. 24-25]. The obsolete proverb still swine eats eats all the draff, very popular in the $16-17 \mathrm{cc}$. is analog to the modern one actions speak louder than words, e.g.: "Wives may be merry, and yet honest too: We do not act often jest and laugh; 'Tis old but true, 'Stll swine eats all the draff'." [ibid, IV. ii. 110-112]. Now dialectal saying to make a shift 'to do one's best' is very close to the modern to pull out all the stops, as in Macbeth: “...he took up my legs sometime, yet I made a shift to cast him." [ibid, II.iii. 47]. The archaic expression somewhat revived in the $19 \mathrm{c}$. to the utterance is a good analog to to the bitter end: “...come fate into the list, And champion me to the utterance!" [ibid, III. i. 71]. Another old saying of that kind is cut and long tail 'all sorts of people (from the literall sense 'horses and dogs with long and cut tails')' is used by W. Shakespeare in the modern meaning come rain or sunshine, come hell or high water, etc. E.g.: "Shal. He will maintain you like a gentlewoman. Slen. Ay, that I will, come cut or long-tail, under the degree of a squire." [ibid, The Merry Wives of Windsor III. iv. 45-48].

Other lexical items follow the same suit and serve as analogs to the modern expressions, as in Macbeth: “...screw 
your courage to the sticking place" [ibid, I. vii. 60.], as allusion to the "screwing up of the peg of a musical instrument until it becomes tightly fixed in a hole' [10, p. 1903] - modern to brace up; to hold one's dainties cheap [8, II. i. 21] modern 'to have little respect for someone' (not to care about someone); to set in one's staff [ibid, 50] 'to remain in one's position' (stick to one's guns, stand pat); back-friend [ibid, IV. i. 37.] 'fair-weather friend'; fewness and truth 'in a nutshell, in a capsule form'; in few (both in Hamlet) [ibid, I. iii. 126] 'in short'; to keep counsel [ibid, IV. ii. 11] 'to keep secret'; in fine [ibid, II. ii. 69] 'at the end'; out of frame [ibid, I.ii.20], 'out of order'; to do grace [ibid, I.i.131] 'to do honor'; the pith and marrow [ibid, I. iv. 22] 'the gist, the brasstacks, nitty-gritty, bottom-line'; will he, nill he [ibid, V. i. 18] 'willy nilly'; last, and as much containing as all these [ibid, IV. v. 87] 'last but not least'; to the purpose [ibid, V. i. 42] 'to the point'; to be out at elbow 'to be in a fix'; cucullus non facit monachum [ibid, V. i. 257] 'it is not the hood that makes a man a monk'; to have the speed of somebody (Macbeth) [ibid, I. iv. 36] 'to get ahead of'; to sit on brood [ibid, III. i. 174] 'to muse, reflect'; to be out at elbow (from the notion that a person whose clothes are worn at elbows is in a bad condition) 'be in jam, up the creek, etc', as 'Lucio. Do not believe it. Fewness and truth, 'tis thus: Your brother and his lover have embraced." [ibid, II.i. 38-40). "Angelo. 'Elbow is your name? Why dost thou not speak, Elbow? Pompey. 'He cannot, sir: he's out at elbow." [ibid, II.i. 61-62].

On the other hand, when idioms refer to everyday life and rely on common sense, they are either well understood, or preserved in Modern English. Such items are abundant in G. Chaucer's work: "Ne that a monk, whan he is recchelees, Is likned til a fish that is waterlees." [2, Prologue. 179-180]. "It is not the case with the monk, who, being careless to his duty, Is like a fish out of water". "Grehoundes he hadde as swift as fowel in flight..." [ibid, 190]. - "He had grayhounds as fast as birds in flight". "His palfrey was as broun as is a berye." [ibid, 207]. - "His steed was as brown as berry". "He was as fressh as in the month of May." [ibid, 92]. "Harneised wel and sharp as point of spere." [ibid, 114]. - "[He was] equipped well and sharp as the point of spear". "Hir nose tretys, hir eyen greye as glas." [ibid, 152]. - "Her nose[was] well-shaped, her eyes [were] as gray as glass". "And eek as loude as dooth the chapel belle." [ibid, 171]. "And also as loud as bell of the chapel." "His heed was balled, that shoon as any glas." [ibid, 197]. - "His head was bald and shined as glass." "But thilke text heeld he nat worth an oyster." [ibid, 182]. - "But he held the same speech not worth an oyster." "He yaf nat of that text a pulled hen." [ibid, 177]. - "He did not give a plucked hen for that speech."

W. Shakespeare's works also contain such transparent idioms: "Why, what should be the fear? I don't set my life at a pin's fee." (Hamlet) [8, I. iv. 64-65]. "Ay, sir, but 'While the grass grows oft starves the silly steed.” [ibid, III. ii. 365366]. "To wash it white as snow." [ibid, III. iii. 46]. "White his shroud as the mountain snow.” [ibid, IV. v. 36]. "O bosom black as death!" [ibid, 67]. "With all his crimes broad blown, as flush as May.” [ibid, 81]. “...and we ourselves compell'd Even to the teeth and forehead of our faults To give in evidence." [ibid, 62-64]. "His beard was as white as snow." [ibid, 194]. When Hamlet calls the king 'a cut-purse of the empire and the rule' [ibid, III. iv. 99] it is associated with modern pickpocket, with the only difference of getting the money (cutting the strings, which attach a purse to a belt).

It is worth mentioning here that W. Shakespeare has introduced many catch phrases that became current literary quotations. Though being rather old, they are transparent and well understood, due to their reference to everyday realia. E.g.: I know a hawk from a handsaw (=heron) - to know one's onions" [ibid, II. ii. 405-6], caviare to the general [ibid, 466].

One special intermediate case is when other factors come to play. Sometimes obsolete and current idioms differ but in a link verb, as grow to seed (Hamlet) [ibid, I. ii. 136] 'to deteriotate' (modern: to go, run to seed). Or some sayings in the Late Middle-Early Modern English were in use due to the French influence, as to bear in hand 'to abuse, delude, charge, accuse' (French maintenir), as in G. Chaucer: "Of wenches wolde I beren hem on hond, Whan that for syk unnethes myghte they stoned." [2, The Wife of Bath's Prologue. 393-394]. - "I would accuse them of wenching, If they were not so ill that they could hardly stand." Or in W. Shakespeare's Macbeth: "In our last conference, pass'd in probation with you, How you were borne in hand, how cross'd, the instruments, Who wrought with them." [8, III. i. 79-81]. Sometimes the allusions to the well-known sayings of the time are made in the literary works (Macbeth), which are transparent now: "Wouldst thou have that Which thou esteem'st the ornament of life, And live a coward in thine own esteem, Letting 'I dare not' wait upon 'I would,' Like the poor cat I' the adage?" [ibid, I. vii. 41-45]. Here the allusion is made to the old saying The catte wyll fishe eate, but she wyl not her feete wette [10, p. 221] - a cat will eat the fish without getting her feet wet.

Summary. Idioms in the Late Middle-Early Modern English in the works of G. Chaucer and W. Shakespeare reflect cultural background of that time and can be understood though the prism of the social practices. The most productive contributing spheres idioms belong to are hawking, hunting, and other diversions, along with professional fields (military, law). From the inventory angle, there are two groups of the items: the former belong to non-equivalent vocabulary, with no corresponding notions and counterparts in Modern English, and the latter having different language expressions for the same notions. The prospect of further study lies in analyzing larger corpus of material of different genres to reach more definite results.
1. Crystal D (2008) 'Think On My Words'. Exploring Shakespeare's Language. Cambridge University Press.

2. Chaucer G (1992) The Canterbury Tales. NY: Alfred A. Knopf.

3. Drake N (1969) Shakespeare and His Times. NY: Burt Franklin.

4. Forgeng J, McLean W (2009) Daily Life in Chaucer's England. London: Greenwood Press.

5. Heer F (1962) The Medieval World. NY: New American Library.

6. Machnam T (2005) English In the Middle Ages. Oxford, NY: Oxford University Press.

\section{REFERENCES.}

7. Malcolm A (2006) The Palgrave Literary Dictionary of Chaucer. NY: Macmillan.

8. Shakespeare W (1993) The Complete Works of William Shakespeare. London: Henry Pordes,

9. Shewmaker E (2008) Shakespeare's Language. New York: Facts on File.

10. Simpson J, Weiner T (1994) The Compact Oxford English Dictionary. Oxford: Clarendon Press. 